DOI 10.15393/j9.art.2014.752

Светлана Олеговна Захарченко

кандидат филологических наук, старший преподаватель кафедры туризма, Петрозаводский государственный университет (Петрозаводск, Российская Федерачия) zco59@mail.ru

\title{
БИБЛЕЙСКИЕ МЕТАФОРЫ В ПИСЬМАХ ЛЬВА ОПТИНСКОГО*
}

Аннотация. В данной статье впервые предпринят анализ тропики, встречающейся в письмах первого оптинского старца Льва (Наголкина), а именно аллюзий, аллегорий, перифразов и метафор. Наиболее используемые Львом тропы - это «буря искушений», «сердечная нива», «радостная жатва», «рубище страстей», «брак души», «овцы словесные», «воин Христов», «духовное млеко», «мысленный волк», «бревно гордыни». В данных тропах характерна контаминация нескольких библейских цитат и евангельских образов. Встречаются метафоры простые и развернутые. Все метафоры в письмах преподобного Льва Оптинского обладают особой функцией: они актуализируют библейские события, символически описывают внутренний мир человека и указывают путь спасения души. Для старца свойственно авторское употребление тропики, во многом отличающееся от традиционных поэтических образов русской литературы XIX века.

Ключевые слова: Оптина пустынь, старчество, преподобный Лев (Наголкин), эпистолярное наследие, евангельский образ, топика, метафора, эпитет, аллегория, перифраз

B письмах первого оптинского старца Льва (Наголкина) встречаются аллюзии, аллегории и поэтические тропы. Наиболее употребимые - это «буря искушений», «сердечная нива», «радостная жатва», «рубище страстей», «брак души», «овцы словесные», «воин Христов», «духовное млеко», «мысленный волк», «бревно гордыни», «пламень гнева». Для писательской манеры преподобного характерна контаминация нескольких библейских цитат для придания письменной речи высокой стилистической окраски.

Так, в письме к своей духовной дочери Анфии (Кононовой) преподобный Лев использует и цитату из Евангелия, и употребляет образ, указывающий на эту цитату, причем метафора предшествует цитированию: 
...извещаете о постигающей вас, по мнению вашему неудобоносимой буре искушений, - то я, грубый, со дерзновением напоминаю вашей любви Духом Святым изреченный чрез Пророка Давида псалом (26-й): «Господь просвещение мое и спаситель мой кого убоюся?» ${ }^{1}$.

Метафора «буря искушений» косвенно отсылает к евангельской притче: «И поднялась великая буря <...> И встав, Он запретил ветру и сказал морю: умолкни, перестань. И ветер утих, и сделалась великая тишина» (Мк. 4:37-39; Лк. 8:24).

Старец предлагает Анфии вместе с пророком Давидом:

...молиться за творящих нам напасти <..> и Премилостивый Господь Своею Всемогущею Силою запретит нашедшей буре и в мгновение ока превратит в благоприятную тишину ${ }^{2}$.

Мир души человеческой символически представляет море страстей. Молитва - призыв к Богу, помощь Божия наступающее душевное спокойствие.

В письме к своим духовным чадам, семейству петербургского купца Лесникова, старец использует несколько метафор, восходящих к различным евангельским образам:

Духовная жизнь внутреннего человека, по сказанию Святых Отцов, разделяется на две части: деятельную и умозрительную. Первая есть - сеятва добродетелей на сердечную ниву исполнением заповедей, вторая - радостная жатва: брак души - очищенной от страстей заповедями, - с Женихом Христовым в тайных чертогах сердца совершаемый. <..> Кто несмысленно и дерзостно пожелает, не совлекши с себя рубище страстей, и не облекшись в брачную одежду чистоты, войти в брачный чертог, внутреннюю клеть сердца своего, где непрестанным Богомыслием совершается любовное беседование человека с Богом, - таковому, по словам Евангельским, связываются руки и ноги, то есть: прекращается течение его по пути благочестия ${ }^{3}$.

Метафора «сердечная нива» отсылает читателя к Первому посланию апостола Павла коринфянам: «Мы соработники у Бога, [а] вы Божия нива» (1 Кор. 3:9). Метафора «радостная жатва» восходит к евангельской притче о жизни вечной: «Сеющий и жнущий вместе радоваться будут» (Ин. 4:36). В Евангелии сеющий и жнущий уже теперь, а не через четыре 
месяца или спустя столетия радуются вместе, т. е. они соединены во времени. У старца сеющий и жнущий - один человек. Аллюзия «брак души» и метафора «рубище страстей» и восходят к евангельской притче о брачном пире, где брачные одежды - символ добродетелей сердечных, а рубище символически означает человеческие страсти. С помощью метафор «сердечная нива», «радостная жатва», «рубище страстей» и аллюзии «брак души» преподобный описывает внутреннего, духовного человека, который и есть тот, кто «собирает плод в жизнь вечную», очистив свое сердце и «сочетавшись со Христом» (Кол. 3:3).

Человек, хотящий спастись, должен жить по заповедям Божиим, уточняет старец в письме к супругам Кулешовым, потому что:

...по своей воле, хотя и много мнимая сеяти, но жатва бывает тщетна ${ }^{4}$.

Контаминация понятий мнимого сеяния с тщетностью жатвы восходит к евангельской притче о сеятеле (Лк. 8:5-15): «много мнимая сеяти» значит, бросать семя на дороге или на камень, где ничего не вырастет. Под сеятелем нужно понимать Самого Господа нашего Иисуса Христа. По толкованию святых отцов, только о Нем можно сказать, что Он сеет «семя Свое». Все остальные, сеющие слово Божие, сеют не свое семя, но семя, принадлежащее Богу. Учитель, который преподает не слово Божие, а какое-то собственное учение, на самом деле распространяет лжеучение.

Метафора «мысленный волк» встречается в молитвах ко Святому Причащению: «...да от мысленного волка звероуловлен буду» ${ }^{5}$.

В Евангелии под волками понимаются лжепророки: «Берегитесь лжепророков, которые приходят к вам в овечьей одежде, а внутри суть волки хищные» (Мф. 7:15). Это внешний враг, о чем старец пишет своей духовной дочери Тавифе:

Пуститься ей бедственно <...> внешнем зверям волкам и медведям и прочим <...> А от мысленных зверей полчищ диавольских дабы со своею дерзостию не пострадать еще пребедственнее всего ${ }^{6}$. 
«Мысленный зверь», по мнению старца, это греховные мысли, внутренний враг. В письме о. Льва Анфии (Кононовой) образ мысленного волка раскрывается через аллегорию, где замысел сравнивается с искрой, а гнев - это разгоревшееся пламя:

...яростною частию - это за гордость и за презорство других вам попустилось, что мысленный волк вам поругался и в таковое неистовство вас ввел <...> в тебе закрались гордостные помыслы $<\ldots>$ Таковые помыслы, гнездившиеся в вашей душе, подобно искре, тлеющей в изгребии, вдруг вспыхнули от ветра в пламень жестокого гнева, при прилучившейся малой противной вам вещи ${ }^{7}$.

Метафора «пламень жестокого гнева» является важным композиционным средством, она логически связана с образом мысленного волка.

Преподобный Лев использует в письмах перифразы «овцы словесные», «воин Христов». В письме к строителю Тихоновой пустыни Геронтию: «...врученные вам от Бога словесныя овцы» ${ }^{8}-$ это монахи. Уже в памятниках русской литературы ХІ века зафиксирован образ «святого стада»", «стада богословесных овец» ${ }^{10}$. Словосочетание «словесные овцы», «словесное стадо» имеет значение «духовные», «духовное» и употребляется как стилистическая формула, раскрывающая понятие «христианин». Эта формула на протяжении восьми веков не претерпевает особых изменений, кроме опускания первой части перифрастической конструкции «богословесныя» ${ }^{11}$ или же замены на лексему "христоименитые» ${ }^{12}$ В перифрастических конструкциях о христианах использованы словосочетания, понятные русскому человеку, но по семантике они противопоставлены аллофону «крестьянин, земледелец», так как обозначают стадо или пастуха этого стада, который в Библии именовался Авелем в контраст земледельцу Каину. В основе христианского учения лежит слово Божее, верующие - это последователи пастыря-Бога, учения Божия, «словесные овцы». В целом образ «стадо - пастух - овца» в древней русской литературе сохраняет евангельскую традицию [2, 330].

Христианское спасение семантически выходит из формулы проповедничества «пасти стадо Христово». «Спастись» 
фонематически перекликается с «паствой» и с «пасти», то есть, проповедывать. «Глава Церкви есть Сам Господь наш Иисус Христос, а члены и Пастыри, их же Дух Святый постави пасти Церковь <курсив мой. - C. 3.> суть архиереи и иереи и весь клир» ${ }^{13}$.

Перифраз «воин Христов» в письме старца Василию Никитичу Кобцову ${ }^{14}$ восходит к евангельскому понятию «добрый воин Иисуса Христа» (Еф. 6:12; 2 Тим. 2:3) и в сочетании с перифразом «словесные Христовы овцы» характеризует не просто христианина, но - монастырского насельника:

Желаю, чтобы исполнилось это желание ваше - чтобы сделаться еще и воином Христовым <...> разгорается в вас сердечное усердие и благое произволение, дабы по заповеди Господней <...> оставить все и отрещися себя самого, и вземши крест терпения последовать Христовой Жизни - (то есть) поступив во ограду словесных Христовых овец в монастырь, - сему я духовно радуюсь и не воспрещаю тебе вступить в Христово воинство ${ }^{15}$.

Метафора «духовное млеко» («слово Божие») отсылает нас к апостольским посланиям: «Я питал вас молоком, а не твердою пищею, ибо вы были еще не в силах, да и теперь не в силах, потому что вы еще плотские» (1 Кор. 3:2-3); «Ибо, судя по времени, вам надлежало быть учителями; но вас снова нужно учить первым началам слова Божия, и для вас нужно молоко, а не твердая пища. Всякий, питаемый молоком, несведущ в слове» (Евр. 5:12-13); «Как новорожденные младенцы, возлюбите чистое словесное молоко, дабы от него возрасти вам во спасение» (1 Пет. 2:2).

Старец употребляет данную метафору и в другом контексте: «Имели одну матушку и от одного воспитаемы духовного млека» $»^{16}$. «Духовное млеко» - это учение пастыря. Таким образом, можно говорить о формуле старчества, согласно которой возросший на слове Божием пастырь питает духовным молоком пасомую им общину.

Метафоре «бревно гордыни» предшествует цитата:

...надо вспоминать совет евангельский (Мф. 7:3; Лк. 6:41) вынуть прежде бревно из собственнаго глаза - то есть: из своего ума гордость $<\ldots>$ и тогда $<\ldots>$ возможем вынуть (искусно) сучец из ока 
ближняго <..> а если, не просимый, судил ты сучец в глаз братнем - знай известно, что твой глаз завален бревном гордыни ${ }^{17}$.

В Евангелии аллегорическое сравнение выражает степень греховности изобличителя и изобличенного, характеризуя фарисеев. В письме старца внимание акцентируется на внутреннем греховном состоянии человека, а именно - гордыне.

Небезынтересна аллегория в одном из писем старца к своей духовной дочери, вдове петербургского купца, А. Т. Лесниковой:

Такая мысль хранит спокойствие чувств и духа; она есть благодетельница внутреннего христианина во всяком роде жизни; она есть хранительница непоколебимости ума во всяком случае, как бы мудрый всадник, управляя стремлениями страстей, ограничивает оные от непрестанных движений, и - колесницу тела нашего, возимую иногда свирепыми [и тщетными] склонностями, благополучно управляет к чаемой цели, или - и самую душу к Отечеству Небесному! ${ }^{18}$.

В Ветхом Завете всадник - это человек из народа Израиля, а образ колесницы связан с пришествием Господа: «Илия взят в огненной колеснице на небо <...> вдруг явилась колесница огненная и кони огненные, и разлучили их обоих, и понесся Илия в вихре на небо <...> Елисей же смотрел и воскликнул: отец мой, отец мой, колесница Израиля и конница его» (4 Цар. 2:1, 11-12).

В Ветхом Завете образы и колесницы, и всадника могут относиться к человеку: «Говорит Господь Бог: вот, Я приведу против Тира от севера Навуходоносора, царя Вавилонского, царя царей, с конями и с колесницами, и со всадниками <...> От множества коней его покроет тебя пыль, от шума всадников и колес и колесниц потрясутся стены твои» (Иез. 26:7-10).

В Новом Завете образ всадника, и образ колесницы описывают силы небесные: «Я взглянул, и вот, конь вороной, и на нем всадник, имеющий меру в руке своей» (Откр. 6:5); «И из дыма вышла саранча на землю, и дана была ей власть, какую имеют земные скорпионы <..> И сказано было ей, чтобы не делала вреда траве земной, и никакой зелени, и никакому дереву, а только одним людям, которые не имеют печати Божией на челах своих <..> На ней были брони, как 
бы брони железные, а шум от крыльев ее - как стук от колесниц, когда множество коней бежит на войну» (Откр. 9:7-11).

Аллегория о. Льва опирается на евангельскую традицию и описывает христианина, направляемого Богом посредством евангельских заповедей, где всадник - это божественное начало в человеке, а колесница тела - метафора тварности человеческой природы.

В литературе существует ряд исторических жанровых форм, предписывающих авторам использовать аллегории. Наиболее известными жанрами, относящимися к этому ряду, являются басня, моралите, притча, а также многие произведения средневековой восточной поэзии. Аллегории в письмах преподобного Льва восходят к евангельским притчам $[1,256]$ и не являются рефлексами активированных концептуальных метафор [3].

В письмах преподобного Льва встречаются как прямое, так и скрытое цитирование в виде аллегорий, а также поэтические образы, созданные на основе евангельских.

И писатель, и старец воздействуют на душу человека, идущего по пути спасения. Поэтому неслучайно присутствие библейских образов в эпистолярном наследии первого оптинского старца Льва, который обладал особым знанием евангельских истин. Ведь старец - это воин Христов, пасущий свою паству и питающий ее словом Божиим.

\section{Примечания}

Статья публикуется в рамках проекта N 12-04-12025 «Эпистолярное наследие преподобного старца Льва Оптинского». РГНФ, 2012-2014 гг.

1 НИОР РГБ. Ф. 214. Опт. 370. Л. 352; Письма Великих Оптинских старцев. М., 2007. № 6.

2 НИОР РГБ. Ф. 214. Опт. 370. Л. 352.

3 НИОР РГБ. Ф. 214. Опт. 371. Л. 344. № 68; Письма Великих Оптинских старцев. М., 2007. № 14.

4 НИОР РГБ.Ф. 214. Опт. 377-1. Л. 26 об. - 27 об.

5 Молитва 2-я ко Святому Причащению (св. Иоанна Златоуста).

6 Ф. 213. К. 74. Ед. хр. 32. Л. 3.

7 НИОР РГБ. Ф. 214. Опт. 370. Л. 358-359; Письма Великих Оптинских старцев. М., 2007. № 6. 
НИОР РГБ. Ф. 214. Опт. 370. Л. 76.

9 Житие Феодосия Печерского // Библиотека «Страницы истории Отечества». Л.: Лениздат, 1983. С. 164, 241, 276.

10 Житие Феодосия Печерского, 232-233.

11 Житие Авраамия Смоленского // ПДРЛ. I пол. ХІІІ в. Москва: Худ. лит-ра, 1982. С. 82, 90; Житие Сергия Радонежского // ПДРЛ. Конец XIV - cep. XV в. М.: Худ. лит-ра, 1981. С. 274, 330, 326.

12 Житие Сергия Радонежского, 386, 492.

13 НИОР РГБ. Ф. 214. Опт. 383. Л. 56.

14 Родитель Кобцова принадлежал к раскольничей секте. А сам Василий Кобцев стал оптинским монахом Владимиром.

15 НИОР РГБ. Ф. 214. Опт. 371. Л. 400. № 97.

16 НИОР РГБ. Ф. 214. Опт. 370. Л. 335; Письма Великих Оптинских старцев. М. 2007. № 4.

17 НИОР РГБ. Ф. 214. Опт. 371. Л. 347 об.

18 НИОР РГБ. Ф. 214. Опт. 371. Л. 24 об. №71.

\section{Список литературы}

1. Захарченко С. О. Черты старчества в письмах преподобных Макария и Амвросия Оптинских // Проблемы исторической поэтики. Петрозаводск, СПб.: Алетейя, 2011. Вып. 9: Евангельский текст в русской литературе XVIII-XX веков: Цитата, реминисценция, мотив, сюжет, жанр. Вып. 6. С. 257-268.

2. Коновалова О. Ф. «Плетение словес» и плетеный орнамент конца XIV в. // Труды Отдела древнерусской литературы. М.-Л.: Изд-во Академии наук СССР, 1966. Т. 22. С. 101-111.

3. Петр (Шитиков), иерей. Перспективы когнитивной теории метафоры в библейских исследованиях // Христианское чтение. 2013. № 2. С. 229-242.

\section{Svetlana Olegovna Zakharchenko}

Ph.D. in Philology, Assistant Professor of Petrozavodsk State University (Petrozavodsk, Russian Federation) zco59@mail.ru

\section{BIBLICAL METAPHORS IN LETTERS OF LEV OF OPTINA}

Abstract. This article presents the first analysis of tropes in the letters of the first Elder Lev (Nagolkin) of Optina Pustyn Monastery (Opta's hermitage) - i. e. proverbs, allusions, allegories periphrasis and metaphors. Elder Lev most frequently used such tropes as "the storm of temptations", "the 
heart field", "happy harvest", "rags of the passions", "the marriage of the soul", "verbal sheep", "soldier of Christ", "spiritual milk", "the mind's wolf", "a log of pride". One special thing about these tropes is that they blend together several biblical quotations and the Gospel images. Both simple and extended metaphors are used, and all the metaphors in the letters of St. Lev of Optina have a special function: they actualize biblical events, describe symbolically the inner world of a person and show the way to the salvation of the soul. It is typical of the Elder to use his own unique tropes, which are very different from the traditional poetic images of the Russian literature of the 19th century.

Keywords: tropes, author's metaphor, biblical quotations, salvation, Optina Pustyn Monastery

\section{Reference}

1. Zakharchenko S.O. Cherty starchestva $\mathrm{v}$ pis'makh prepodobnykh Makariya i Amvrosiya Optinskikh [Features of Eldership in the Letters of St. Macarius and Ambrose of Optina]. Problemy istoricheskoy poetiki [The Problems of Historical Poetics]. Petrozavodsk; St.-Petersburg, Aleteyya Publ., 2011. Vol. 9: Evangel'skiy tekst v russkoy literature XVIII-XX vekov: tsitata, reministsentsiya, motiv, syuzhet, zhanr [The Gospel Text in Russian Literature of the 18th-20th Centuries: Quotation, Reminiscence, Motif, Plot, Genre]. Issue. 6, pp. 257-268.

2. Konovalova O. F. «Pletenie sloves» i pletenyy ornament kontsa XIV veka ["Weaving Words" and Braided Ornament the Late Fourteenth Century]. Trudy Otdela drevnerusskoy literatury [Proceedings of the Department of Old Russian Literature]. Moscow-Leningrad, Publishing House of Academy of Sciences of the USSR, 1966, vol. 22, pp. 101-111.

3. Petr (Shitikov), priest. Perspektivy kognitivnoy teorii metafory $\mathrm{v}$ bibleyskikh issledovaniyakh [Prospects for a Cognitive Theory of a Metaphor in Biblical Studies]. Khristianskoe chtenie [Christian Reading], 2013, no. 2, pp. 229-242. 